\title{
Morphological and Histochemical Analysis of the Human Vestibular Fold
}

\author{
Análisis Morfológico e Histoquímico del Pliegue Vestibular Humano \\ Heraldo Lorena Guida \& Neivo Luiz Zorzetto
}

\begin{abstract}
GUIDA, H. L. \& ZORZETTO, N. L. Morphological and histochemical analysis of the human vestibular fold. Int. J. Morphol., 25(3):537-543, 2007.

SUMMARY: A morphological and histochemical study of the human vestibular fold was carried out using routine histological techniques. Seven $\mu \mathrm{m}$-thick histological sections stained with hematoxylin-eosin (HE) and Calleja showed the presence of elastic collagen fibers and seromucous glands in the vestibular fold. Muscle fibers forming the ventricular muscle were also identified. Ultrastructural analyses of the epithelial layer by scanning electron microscopy (SEM) revealed ciliated cells and gland ducts opening on the epithelial surface. Histochemical analyses were performed on ventricular muscles submitted to nicotinamide-adenine-dinucleotide tetrazolium reductase (NADH-TR), succinate dehydrogenase (SDH), and myofibrillar adenosine triphosphatase (mATPase) reactions. Based on these reactions, it was observed that the muscle is formed by three types of muscle fibers: slow-twitch oxidative (SO), fast-twitch oxydative glycolytic (FOG) and fast-twitch glycolytic (FG) fibers distributed in a mosaic pattern. The fiber frequency was $22.7 \%, 69.9 \%$ and $7.4 \%$, respectively. The higher frequency of SO and FOG fibers characterized the muscle as having aerobic metabolism and resistance to fatigue. The ventricular muscle was considered fast. The study of the neuromuscular junctions performed after nonspecific esterase reaction showed that they are of the en-plaque type and have multiple occurrences in the ventricular muscle.
\end{abstract}

KEY WORDS: Larynx; Vestibular fold; Morphology.

\section{INTRODUCTION}

The larynx is divided into the supraglottic, glottic and subglottic regions, each serving different functions. The false vocal cords, also known as the ventricular or vestibular folds, are two thick, sagittally oriented, individually sized mucosal duplications arising from the wall into the lumen of the supraglottic space and forming the medial wall of the laryngeal ventricle (Kutta et al., 2004).

According to Perelló (1978), the vestibular folds represent the medial sphincter protecting the larynx, its lower part being formed by the vocal folds and the upper part by the epiglottis. This way, they perform the primary function of the larynx from the phylogenetic point of view: the sphincteric action of preventing the entrance of strange bodies into the respiratory tract.

The fold is characterized by the presence of pseudostratified ciliated columnar-type respiratory epithelium. The cell elements predominating in this epithelium are the ciliated columnar cells and the caliciform cells. According to Bak-Pedersen and Nielsen (1986), vestibular folds play a fundamental role in the lubrification mechanism of the laryngeal epithelium, since the number of subepithelial glands found in this fold was greater (128 gland/ $\left.\mathrm{cm}^{3}\right)$ in comparison with the vocal fold $\left(13 \mathrm{gland} / \mathrm{cm}^{3}\right)$.

The analysis of the vestibular fold tissue revealed three distinct muscle bundles: a posterolateral layer, a thin anterolateral muscle and an anteromedial muscle bundle. These fibers may exert some pressure on the vestibular folds, which contributes to an adductor function (Reidenbach, 1998) .

Kotby et al. (1991) carried out histological studies of the laryngeal ventricle, and found the presence of ventricular muscles in $95 \%$ of the cases. The authors stated that the muscle largely varies from one larynx to another; at times few fibers appear to be spread out in the ventricular 
fold substance, or the fibers are more numerous and form oval or circular muscle bundles.

Phonation changes related to the vestibular fold structure have been described in specialized literature, and are cited as ventricular dysphonia or vestibular dysphonia (Maryn et al., 2003).

Knowledge about the vestibular fold is important to surgeons accessing the larynx. Fukuda et al. (1990) described a surgical technique of cordectomy followed by displacement of the ventricular fold. According to the results obtained in their study, from the 11 patients who underwent surgical procedure, 5 presented normal voice, 5 had hoarse voice and only 1 patient had rough and hoarse voice.

The present research aimed to carry out a morphological and histochemical analysis of the human vestibular fold in order to provide more information about the structural and functional characteristics of this important organ.

\section{MATERIAL AND METHOD}

Twenty four larynxes having neither mucosal nor laryngeal muscle pathologies were extracted from 14 male and 10 female adult cadavers during autopsy, their ages ranging between 54 and 71 years old and a mean post mortem time of six hours. The material was collected at the Department of Pathology (School of Medicine, UNESP-Botucatu-SP) after approval by the Research Ethics Committee .

Histological Study. The vestibular folds obtained from six larynxes were submitted to the usual histological techniques, and cut into $7 \mu \mathrm{m}$-thick sections transversal to the larger fold axis. The sections were stained with hematoxylin-eosin (HE) and Calleja for analysis of the main morphological characteristics of the vestibular folds.

Histochemical study of muscle fibers. The vestibular folds of the ten larynxes were removed from the laryngeal cavity and reduced to fragments, which were individually immersed in $-160^{\circ} \mathrm{C}$ liquid nitrogen using tweezers. This material was stored in a dewar flask containing liquid nitrogen until microtomy process.

The frozen blocks were transferred to a cryostat chamber (LEICA CM 1800) at $-20^{\circ} \mathrm{C}$. Each block was fixed perpendicularly by one of the extremities to a metal stud using optimal critical temperature (OCT). Ten $\mu \mathrm{m}$-thick serial sections were obtained from the medial portion and transversally to the larger axis of the vestibular folds.
The sections were submitted to nicotinamide-adeninedinucleotide tetrazolium reductase-NADH-TR (Pearse, 1972) and succinate dehydrogenase - SDH (Wegman \& TordetCaridroit, 1960) reactions, as well as myofibrillar adenosine triphosphatase - mATPase (Brooke \& Kaiser, 1970) reaction at acid preincubation.

The material was analysed by histology and for the presence of different types of muscle fibers. Measurements were made in the middle area of the ventricular muscle (80 fibers for each muscle).

Histochemical study of neuromuscular junctions. In order to study neuromuscular junctions, the vestibular folds of four larynxes were dissected, and the ventricular muscles were fixed in Karnovsky liquid for one hour at room temperature. Then, they were longitudinally cut into four sections, which were submitted to nonspecific esterase reaction (Lehrer \& Ornstein, 1959).

Scanning electron microscopy. The vestibular folds taken from the four larynxes were dissected and previously fixed by immersion in modified Karnovsky solution containing 2.5\% glutaraldehyde, $2 \%$ paraformaldehyde in $0.1 \mathrm{M}$ sodium phosphate buffer at pH 7 (Karnovsky, 1965). The fold samples were fixed at $4^{\circ} \mathrm{C}$ for 24 hours, rinsed in sodium phosphate buffer solution and, then, postfixed in $1.0 \%$ osmium tetroxide solution at $4^{\circ} \mathrm{C}$ for two hours. The specimens were posteriorly immersed in $2.0 \%$ tannic acid for ninety minutes, dehydrated in an ascending series of ethanol solutions from $70 \%$ to absolute and embedded in isoamyl acetate for three hours.

The specimens were dried in a Balzers CPD-010 critical point dryer using liquid carbon dioxide. Then they were mounted on metal studs, sputter-coated with gold (Balzers MED-010) and examined in the scanning electron microscope (FEM 515) at $15 \mathrm{Kv}$.

\section{RESULTS}

Morphological aspects. Vestibular folds, also called ventricular folds or false vocal cords, are formed by fibroelastic and adipose tissue, muscle fibers and a vestibular ligament covered by mucosa. The pinkish mucosa of each vestibular fold covers the thin vestibular ligament which is attached anteriorly to the thyroid angle below the fixation point of the epiglottis, and posteriorly to the anterolateral surface of the arytenoid cartilage above the vocal process.

The ventricular folds form two flat laminae having two faces and two edges. The upper face corresponds to the 


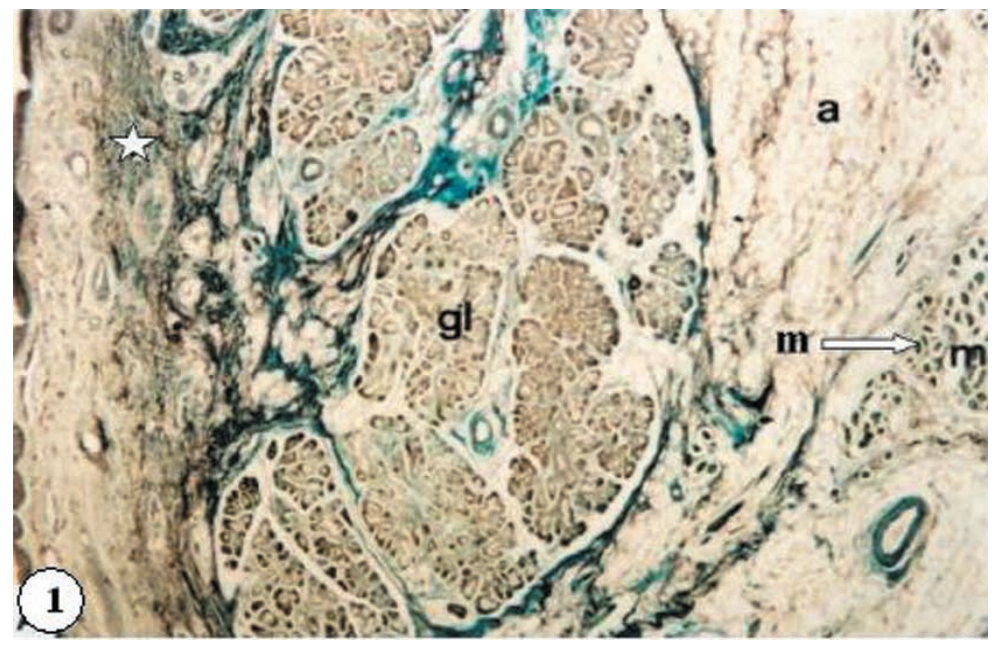

Fig. 1. Photomicrograph of the transversal section of human vestibular fold, $7 \mu \mathrm{m}$,Calleja, showing collagenous and elastic fibers $(\mathrm{H})$, seromucous glands (gl), muscle fibers (m) and adipose tissue (a), 160x.

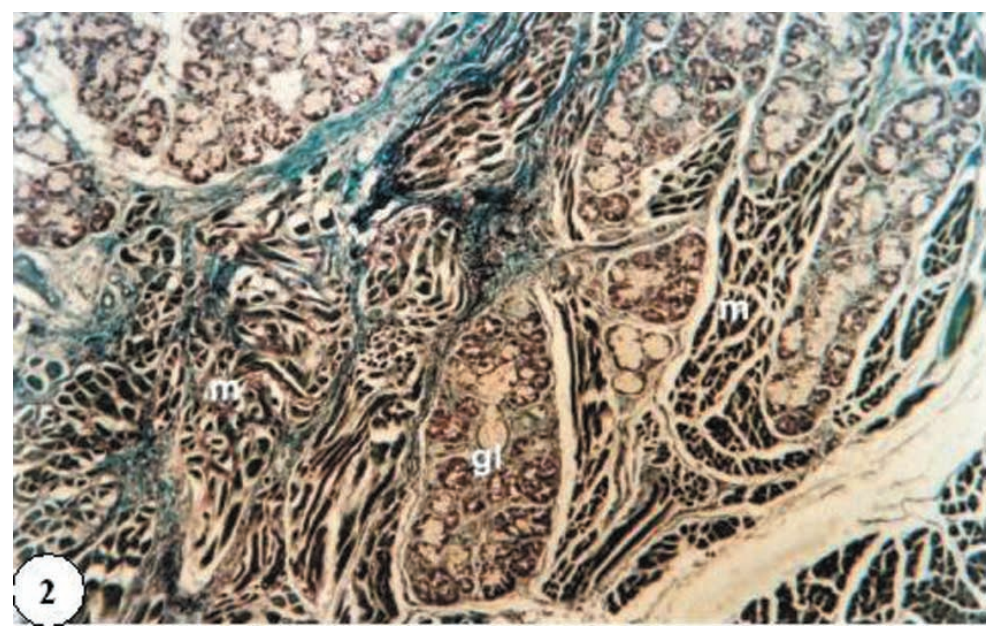

Fig. 2. Photomicrograph of the transversal section of human vestibular fold, $7 \mu \mathrm{m}$, Calleja, showing muscle fibers (m) and seromucous glands (gl), 400x.

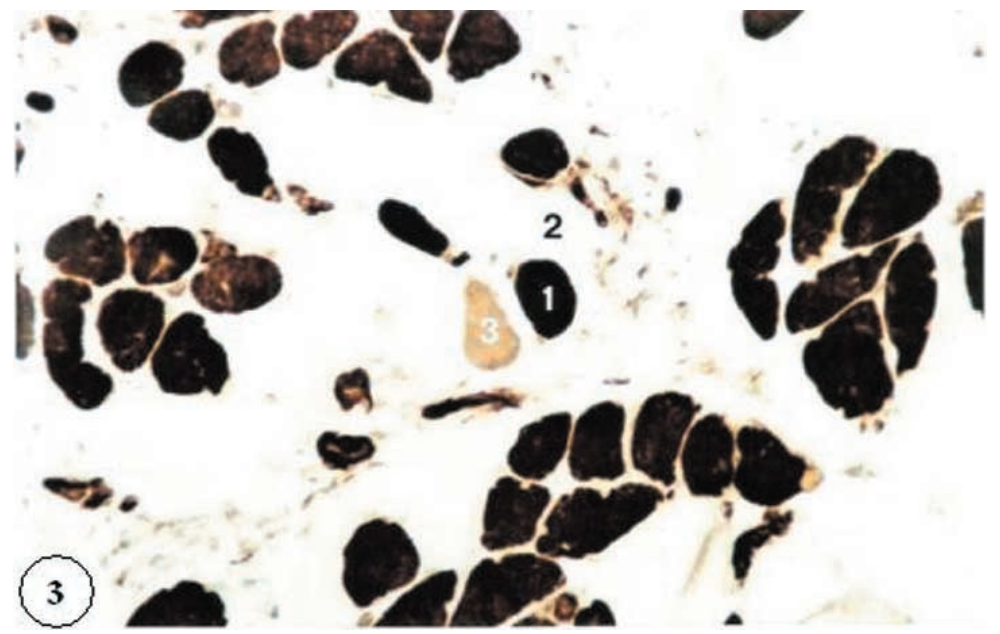

Fig. 3. Photomicrograph of the transversal section of human ventricular muscle, $10 \mu \mathrm{m}$, acid mATPase showing different types of muscle fibers: 1- SO, 2 - FOG and 3 - FG, 400x. supraglottic area of the larynx (laryngeal vestibule); the lower face forms the internal wall of the laryngeal ventricle; the outer edge extends to the aryepiglottic fold without a precise margin. The inner edge is free in all its extension, and is directed to the glottic opening.

The histological analysis of the human vestibular folds revealed the presence of muscle fibers constituting the ventricular muscle which was present in all the cases under study. Nevertheless, the amount and shape of the fiber bundles varied from one larynx to another, and it was possible to identify few muscular fibers scattered in the conjunctive tissue (Fig. 1), compact fascicles interposed between the conjunctive tissue and the seromucous glands (Fig. 2), as well as bundles of circular or ovalshaped muscle fibers (Figs. 3 and 4).

Collagenous and elastic fibers were observed in the vestibular fold (Fig. 1), and they presented an irregular disposition in the subepithelial layer. Seromucous glands were also found in the fold (Figs. 1 and 2), their secretion being responsible for lubricating the laryngeal mucosa by ciliar action (Fig. 5).

The epithelium of the vestibular fold was characterized as a respiratory epithelium presenting ciliated cells and calciform cells; opening of gland ducts were also identified on the epithelial surface (Fig. 5).

Histochemical organization of muscle fibers. Histochemically the sections treated with acid mATPase and those submitted to SDH and NADH-TR reactions presented three types of muscle fibers with different reaction intensities (Figs. 3 and 4). This study also showed a mosaictype disposition of muscle fibers.

Based on the histochemical data, it was noted that the ventricular muscle has three types of muscle fibers which, following Peter et al. (1972), were classified as: slow-twitch oxidative (SO) fibers referring to those with strong acid mATPase reaction (slow-contraction muscle fibers), as well as intense SDH e NADH-TR reactions (high oxidative metabolism); fast-twitch oxydative glycolytic (FOG) fibers, which presented weak acid mATPase and intermediate SDH and NADH-TR reactions; and fast-twitch 


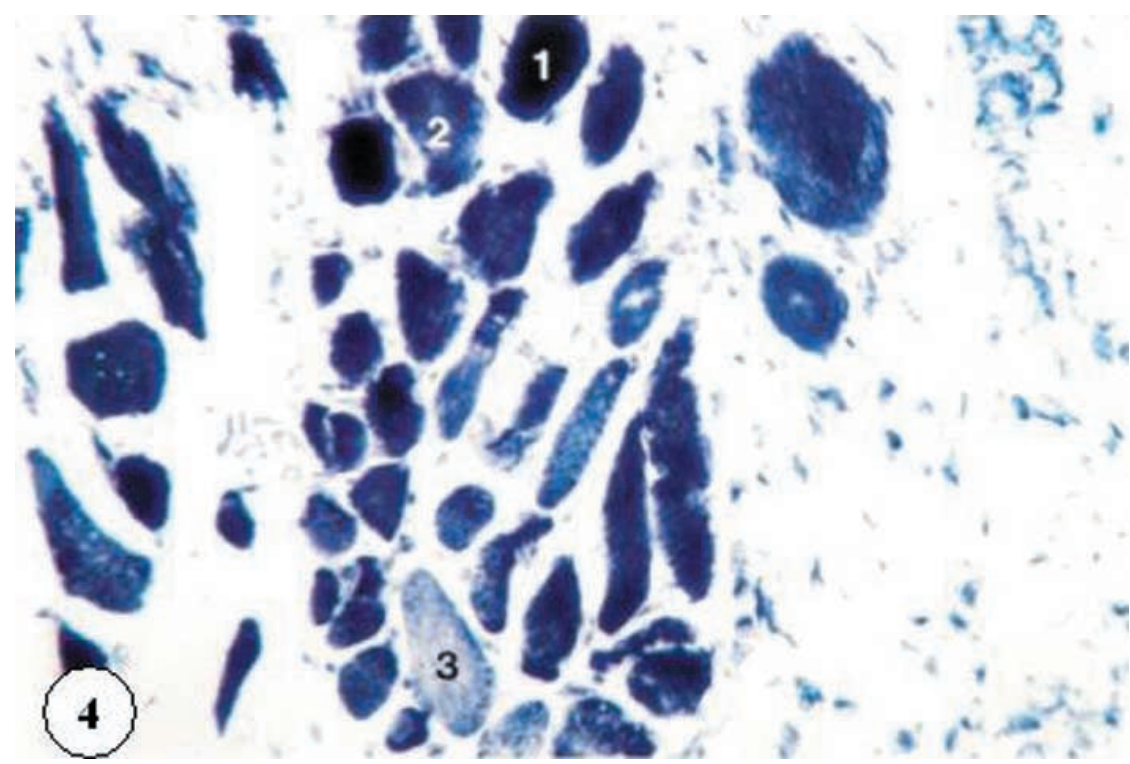

Fig. 4. Photomicrograph of the transversal section of human ventricular muscle, $10 \mu \mathrm{m}$, NADH-TR, showing different types of muscle fibers: 1- SO, 2 - FOG and 3 - FG, 400x.
The enzimatic reactivity of the fiber types in the human ventricular muscle can be represented as seen on Table I. The median percentage differences between the types of muscle fibers and the groups of SO muscle fibers were considered versus the groups of fast-contraction (FOG and FG) muscle fibers as described on Table II.

Neuromuscular Junctions. The morphological analysis of the neuromuscular junctions in the human ventricular muscle was performed in integral preparations after nonspecific esterase reaction.

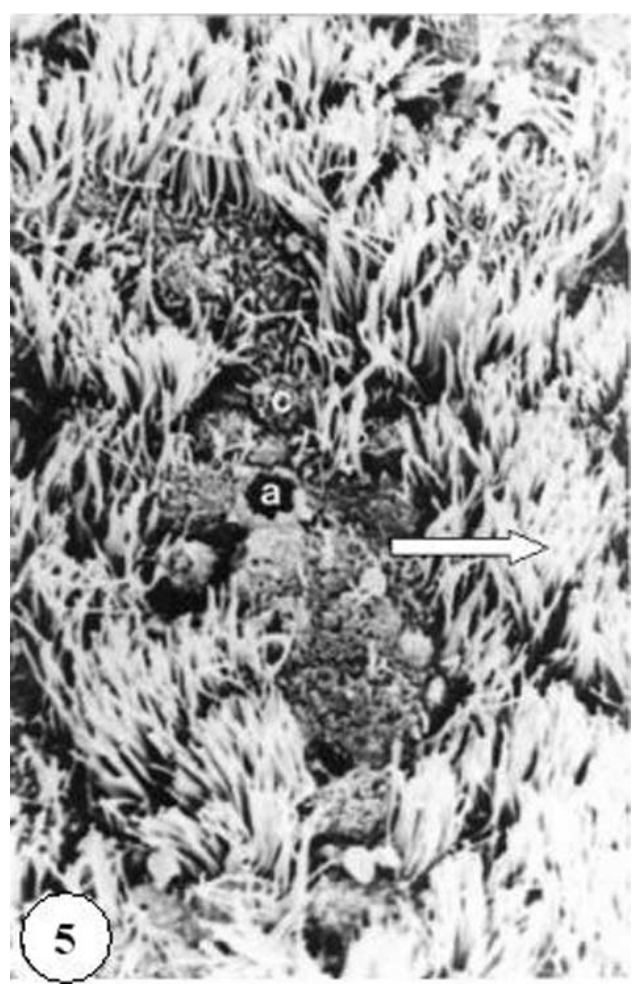

Fig. 5. SEM, respiratory mucosal surface, human vestibular fold, ciliated cells (arrow), caliciform cells (c) and gland duct opening (a), 463x.

glycolytic (FG) fibers, i.e., those presenting intermediate acid mATPase reaction (fast-contraction muscle fibers), weak SDH and NADH-TR (low oxidative metabolism) reactions.
The neuromuscular junctions are situated in the medial third of the muscle fibers and are of the en-plaque type. The plaques are aligned in such a way that the neuromuscular junctions run along the major axis of their respective muscle fibers. Multiple motor plaques, that is, two plaques on the same muscle fiber were also observed (Fig. 6).

\section{DISCUSSION}

The vestibular fold extends anteriorly from the thyreoid cartilage and posteriorly to the arythenoid cartilage. Muscle fibers were found in the vestibular fold in $100 \%$ of the cases studied. The fiber bundles largely varied from one larynx to another. Few fibers were at times scattered in the ventricular fold substance, or were more numerous and formed oval or circular muscle fascicles. Similar results are described in the literature, which reports the presence of muscle fibers in $95 \%$ of the larynxes studied (Kotby et al.).

Collagenous and elastic fibers, which originate vestibular ligaments (Perelló, 1978; Kutta et al., 2004), were identified in this study. Seromucous glands were also observed in the fold, as noted by other authors (Bak-Pedersen \& Nielsen).

According to Sato \& Hirano (1998), the basic functions of the larynx are to act as a protective sphincter, to allow air passage, to produce sound, as well as to provide defense against viruses and bacteriae. All these functions 


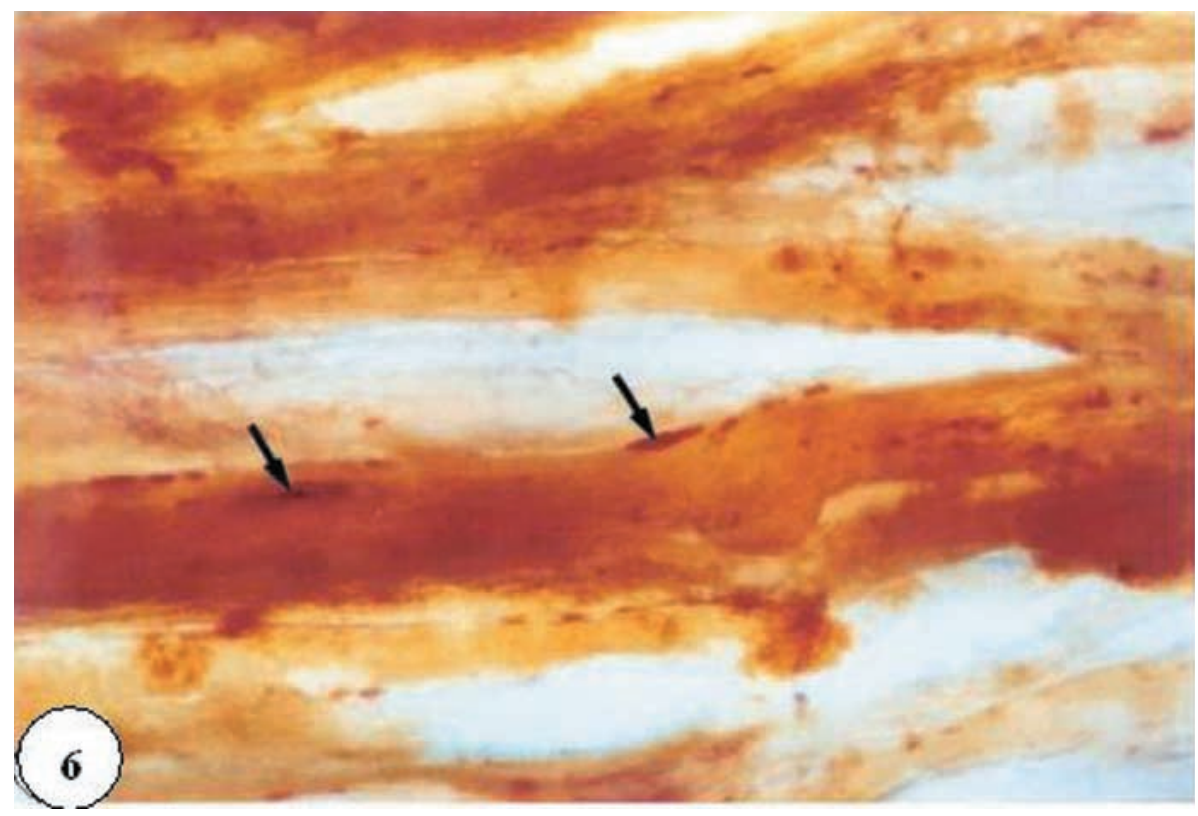

Fig. 6. Photomicrograph of neuromuscular junctions of human ventricular muscle (arrows), nonspecific esterase reaction, 400x.

Table I. Enzymatic reactivity of SO, FOG and FG muscle fibers in the human ventricular muscle.

\begin{tabular}{lccc}
\hline FIBERS & $\begin{array}{c}\text { ENZYMES } \\
\text { mATPase, } \\
\text { NADH } 4.6\end{array}$ & SDH \\
\hline SO & +++ & +++ & +++ \\
FOG & + & ++ & ++ \\
FG & ++ & + & + \\
\hline+++ strong reaction & ++ intermediate reaction + weak reaction
\end{tabular}

Table II - Percentage of SO, FOG and FG fibers types in the human ventricular muscle.

\begin{tabular}{lcccc}
\hline Fibers Types & SO & FOG & FG & FOG and FG \\
\hline Mean & 22.7 & 69.9 & 7.4 & 77.3 \\
Standar deviation & 5.3 & 2.0 & 3.5 & 5.3 \\
\hline
\end{tabular}

require fluid secretion by the laryngeal glands. The authors above state that the serous acinar glands produce protein material necessary to the local immune system. The amount and viscosity of the mucus produced by the laryngeal glands have an effect on mucociliary transport.

The classification of muscle fibers followed Peter $e t$ al., who proposed two basic characteristics to distinguish muscle fiber types, namely, the main metabolic pathway (oxidative or glycolic) and contraction (fast or slow), which allowed to determine muscle fibers as SO, FOG and FG.

Since SO fibers have higher oxidative metabolism, therefore a higher NADH-TR threshold level, they present an intense reaction, which is intermediate in FOG fibers and weak in FG fibers. classified as fast. Zorzetto).
SDH enzyme is exclusively intramitochondrial. The reaction is identical to that of NADH-TR, but it does not require coenzyme; it transfers electrons directly to nitroblue tetrazolium, and causes it to precipitate in blue violet color. The fibers are classified according to color intensity, and behave in the same manner as NADH-TR reaction.

Both NADH-TR and SDH reactions were used in the methodology for typifying muscle fibers, while mATPase reaction after pre-incubation in acid $\mathrm{pH}$ was used to study their contraction character.

The frequency of $\mathrm{SO}$ (slow contraction) muscle fibers was $22.7 \%$, and that of FOG and FG (fast contraction) was $77.3 \%$. These findings are consistent with other studies (Bendiksen et al., 1981; Sadeh et al., 1981; Rodeño et al., 1993; Guida \& Zorzetto, 2000), which presented higher percentage values for fast-contraction fibers in analyses of the human vocal muscle. Considering such similarity in the data referring to fiber typification, it is believed that the muscle fibers present in the vestibular fold originate from muscle fascicles belonging to the thyroarytenoid muscle.

There is a fair correlation between contraction speed and mATPase activity of the muscle fiber (Burke et al., 1973). Predominance of FOG and FG muscle fibers correspond to the data obtained in physiological studies of laryngeal muscles of primates, dogs and rabbits (Hall-Craggs, 1968; Hast, 1969), in which the thyroarytenoid muscle was

Analysis of muscle fibers frequency also revealed that the human ventricular muscle is predominantly aerobic oxidative, being therefore resistant to fatigue. Such finding corresponds with those reported by other authors, who also noted that $\mathrm{SO}$ and FOG fibers are predominant in human laryngeal muscles (Claasen and Werner, 1992; Guida \&

In the present study the distribution of SO, FOG and FG muscle fibers exhibited a mosaic-type pattern, which is in accordance with previous data on histochemical analyses of human laryngeal muscles (Rodeño et al.). 
As stated by Ogata (1988), when a motor nerve fiber is triggered (nerve impulse), the axon terminal releases acetylcholine, which diffuses through the synaptic cleft and binds to specific receptors on the sarcolemma. Thus, the motor neuron contributes to the specification of the histochemical type of the skeletal muscle fiber activated by it (Guth, 1968).

The neuromuscular junctions found in the human ventricular muscle were of the en-plaque type corresponding to fast-contraction fibers (Ogata).

The nervous fibers and the muscle fibers activated by them form a motor unity. The muscle fiber cannot grade its contraction, so it contracts with all intensity when innervated. The strength variations in the muscle contraction are due to the variations in the number of fibers that contract at a certain moment. Both the number of motor units activated and the size of each unit control muscle contraction intensity. In the present study nonspecific esterase technique revealed the presence of neuromuscular junctions in the vestibular fold located in the medial third of the muscle fibers of the ventricular muscle. These findings were similar to those described in the literature (Malmgren et al., 1983).

Two motor plaques on the same muscle fiber were also identified, which characterizes the presence of multiple motor plaques as reported in another study (Rossi and Cortesina, 1965).

ACKNOWLEDGEMENTS: We are grateful to Department of Anatomy, Institute of Biocience, UNESP/ Botucatu - SP, for laboratory use.

GUIDA, H. L. \& ZORZETTO, N. L. Análisis morfológico e histoquímico del pliegue vestibular humano. Int. J. Morphol., 25(3):537543, 2007.

RESUMEN: Fue realizado un estudio morfológico e histoquímico del pliegue vestibular humano a través de técnicas histológicas de rutina. Cortes histológicos de $7 \mu \mathrm{m}$ de grosor fueron teñidos con HE y Calleja, los cuales revelaron la presencia de fibras colágenas, elásticas y glándulas seromucosas en el pliegue vestibular. También fueron identificadas fibras musculares que constituyen el músculo ventricular. Los análisis ultraestruturales de la capa epitelial realizados a través de microscopía electrónica de barrido, mostraron la presencia de células ciliadas, caliciformes y abertura de conductos glandulares en la superficie epitelial. Los análisis histoquímicos fueron realizados con músculos ventriculares sometidos a las reacciones NADH-TR, SDH y mATPasa. En base en estas reacciones se observó que el músculo está constituido por tres tipos de fibras musculares SO, FOG y FG, distribuidas en la forma de mosaico. La frecuencia de las fibras fue de 22,7\%,69,9\% e 7,4\%, respectivamente. La mayor frecuencia de fibras oxidativas SO+FOG caracterizó al músculo, con metabolismo aeróbico, resistente a la fatiga. El músculo ventricular fue considerado como rápido. El estudio de las uniones neuromusculares, después de la reacción de la esterasa inespecífica, evidenció que estas uniones son del tipo placa y de ocurrencia múltiple en el músculo ventricular.

PALABRAS CLAVE: Laringe; Pliegue vestibular; Morfología.

\section{REFERENCES}

Bak-Pedersen, K. \& Nielsen, K. O. Subepithelial mucous glands in the adult human larynx. Acta Otolaryng., 102: 341-52, 1986.

Bendiksen, F. S.; Dahl, H. A. \& Teig, E. Innervation patter of different types of fibres in the human thyroarytenoid muscle. Acta Otolaryngol., 91:391-7, 1981.

Brooke, M. H. \& Kaiser, K. K. Muscle fiber types: How many and what kind? Arch. Neurol., 23:365-79, 1970.

Burke, R. E.; Levine, D. N.; Tsairis, P. \& Zajac, F. E. Physiological types and histochemical profiles in motor units of the cat gastrocnemius. J. Physiol., 234:72348, 1973.
Claasen, H. \& Werner, J. A. Fiber differentiation of the laryngeal using the innibition reactivation myofibrillar ATPase technique. Anat Embryol., 186:341-6, 1992.

Fukuda, H.; Tsuji, D. H.; Kawasaki, Y.; Kawaida, M. \& Sakou, T. Displacement of the ventricular fold following cordectomy. Auris Nasus Larynx, 17:221-8, 1990.

Guida, H. L. \& Zorzetto, N. L. Morphometrical and histochemical study of the human vocal muscle. Ann. Otol. Rhinol. Laryngol., 109:67-71, 2000.

Guth, L. "Throphic" influences of nerve on muscle. Physiol. Rev., 48:645-87, 1968. 
Hall-Craggs, E. C. B. The contraction times and enzyme activity of two rabbit laryngeal muscles. J. Anat., 102:241-55, 1968.

Hast, M. H. The primate larynx. A comparative physiological study of intrinsic muscles. Acta Otolaryngol., 67:8492, 1969.

Karnovsky, M. J. A formaldeyde glutaraldehyde fixative of high Osmolary for use in electron microscopy. J. Cell Biol., 27:1377-152, 1965.

Kotby, M. N.; Kirchner, J. A.; Kahane, J. C.; Basiouny, S. E. \& El-Samaa, M. Histo-anatomical structure of the human laryngeal ventricle. Acta Otolaryngol., 111:396-402, 1991.

Kutta, H.; Steven, P.; Varoga, D. \& Paulsen, F.P. TFF peptides in the human false vocal folds of the larynx. Peptides., 25:811-8, 2004.

Lehrer, G. M. \& Ornstein, L. A diazo compling method for the electron microscopic localization of cholinesterase. Biophysic Biochem. Cytol., 6:399-419, 1959.

Malmgren, L.T.; Rosen, M. \& Gacek, R. R. Three-dimensional computer reconstruction of the distribution of neuromuscular junctions in the thyroarytenoid muscle. Ann. Otol. Rhinol. Laryngol., 92:424-9, 1983.

Maryn, Y.; De Bodt, M. S. \& Van Cauwenberge, P. Ventricular dysphonia: clinical aspects and therapeutic options. Laryngoscope., 113:859-66, 2003.

Ogata, T. Morphological and cytochemical features of fiber types in vertebrate skeletal muscle. Crit. Rev. Anat. Cell. Biol., 1:229-75, 1988.

Pearse, A. G. E. Histochemistry: theoretical and applied. 3. ed. Baltimore, Williams and Wilkins, 1972.

Perelló, J. Morfología fonoaudiológica. 2. ed. Barcelona, Editorial Científico - Médica, 1978.

Peter, J. B.; Barnard, V. R.; Edgerton, C. A.; Gillespie, C.A. \& Stempel, K. E.. Metabolic profiles of three fiber types of Skeletal muscle in guinea pig and rabbits. Biochem., 11:2677-84, 1972.

Reidenbach, M. M. The muscular tissue of vestibular folds of the larynx. Eur. Arch. Otorhinolaryngol., 225:365-7, 1998.
Rodeño, M.T.; Sánchez-Fernández, J. M. \& Rivera-Pomar, J.M.. Histochemical and morphometrical ageing changes in human vocal muscles. Acta Otolaryngol., 113:445-9, 1993.

Rossi, G. \& Cortesina, G. Multi-motor end-plate muscle fibres in the human vocalis muscle. Nature, 206:629$30,1965$.

Sadeh, M.; Kronenberg, J. \& Gaton, E.. Histochemistry of human laryngeal muscles. Cell Molec. Biol., 27:643-8, 1981.

Sato, K. \& Hirano, M. Age-related changes in the human laryngeal glands. Ann. Otol. Rhinol. Laryngol., 107:5259, 1998.

Wegman, R. \& Tordet-Caridroit, C. Histochemical demonstration of succinic dehydrogenase by special inhibition and activation. J. Histochem. Cytochem., 8:348-9, 1960.

Correspondence to:

Heraldo Lorena Guida

Departamento de Fonoaudiologia

Universidade Estadual Paulista - UNESP

Av. Hygino Muzzi, 737, Caixa Postal 181

17525-900

Marília, SP - BRASIL

E-mail: hlguida@marilia.unesp.br

Received: 03-05-2007

Accepted: 22-06-2007 
